\title{
French national policy for flood risk management
}

\author{
Mathieu Morel ${ }^{1}$, Bérangère Basin ${ }^{1}$ and Emmanuel Vullierme ${ }^{1, \text { a }}$ \\ ${ }^{1}$ French Ministry for Environment, Energy and Sea, General Directorate for Risk Prevention, Tour Sequoia, 92055 La Défense Cedex, \\ France
}

\begin{abstract}
With 17, 1 million people and 9 million jobs exposed to river flood, 1, 4 million people and over 850000 jobs exposed to coastal floods, France is very exposed to flood hazards. To address this issue, the French government launched a National Flood Risk Management Strategy associating all flood management parties through the Joint Flood Commission (CMI). After a national public consultation the project of national strategy has been adopted on the 7th October 2014 by the Ministers of Environment, Interior, Agriculture and Housing. This document is the basis of the French Flood Management Policy at national, district, basin and local levels.
\end{abstract}

\section{Context}

The annual average cost of economic losses over the last 30 years in France reaches about $650-800$ million Euros, of which about half is covered by the Natural Disasters insurance system known as "Cat-Nat" implemented by the law of 13 July 1982. This average yearly cost could be much higher in the event of hazards of exceptional intensity.

Although France has been spared from any major disasters seriously impacting the national economy for many decades now, the preliminary flood risk assessment made in 2012 shows that almost one inhabitant in four and one job out of every three is today potentially exposed to these risks (see Figure 1).

Additionally, the effects of climate change with a rise in the average sea level and a possible multiplication in the number of intense storms are all factors aggravating the risk for the coastline and areas surrounding estuaries.

Furthermore, the degree of vulnerability of the exposed populations depends on many factors: the degree of exposure of buildings and strategic locations used for crisis management, the concentration of assets, the complexity and the interdependency of the networks, production modes using just in time practices and therefore the absence of any stocks, the multiplicity of the public and private sector players in charge of services.

To respond to these issues and implement a renewed policy for flood management, Central government has chosen to set out a framework for the thirteen French flood risk management plans (FRMP) promoted by the Directive 2007/60/EC [1] of the European Parliament and the Council of 23 October 2007 on each district. This national strategy for flood risk management brings together measures applicable to fulfill the national policy and to highlight priorities.

The national strategy therefore responds to the significant expectations expressed by all of the partners, especially local authorities, seeking a shared framework to direct the national policy for managing flood risks.

Figure 1. Permanent population urban in river flood

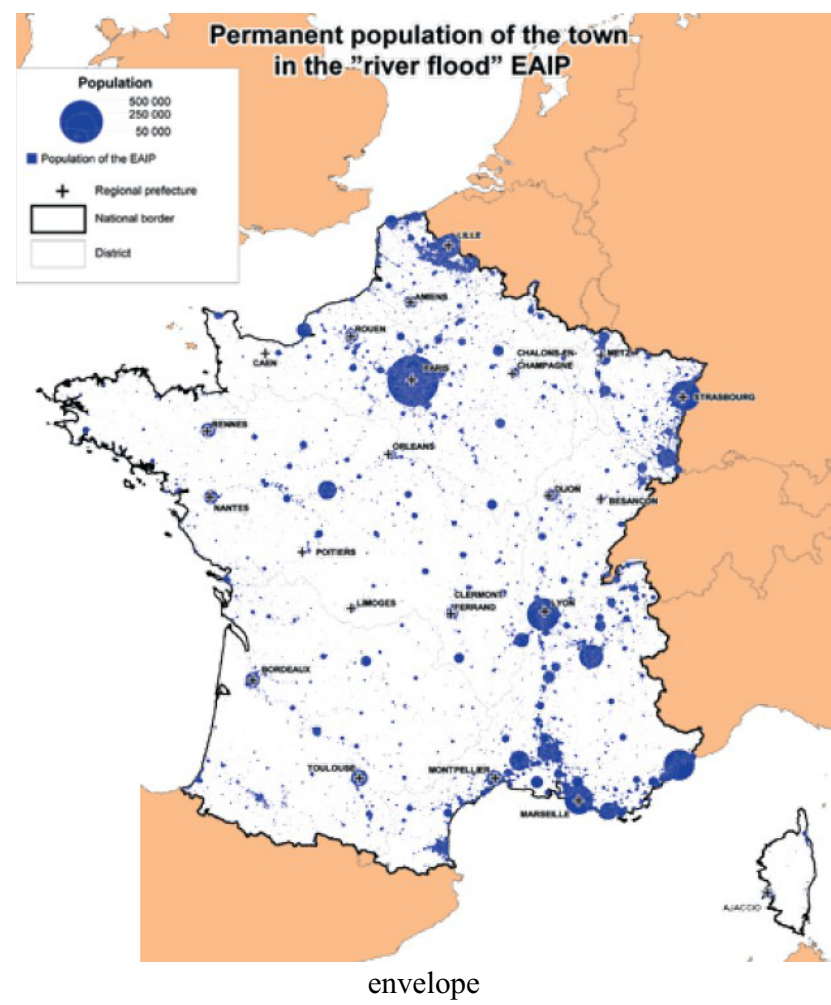

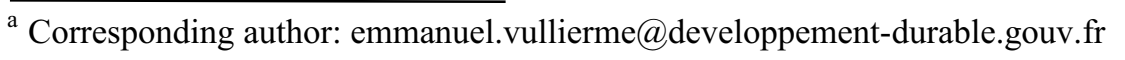




\section{Building a National Strategy}

\subsection{The development of flood governance}

\subsubsection{Principle of a national strategy}

French flood risk management was previously part of the national disaster risk reduction (DRR) policy based on the following 7 pillars:

1. understand and assess risk

2. forecast and early warning systems

3. education and risk awareness

4. integration of the risks in land-use planning

5. reduce vulnerability

6. prepare and manage crisis

7. feedback

The drafting of a National Flood Risk Management Strategy has been set under government responsibility in the transcription law of the Floods Directive.

To associate all interested parties in the writing of the national strategy, the Ministry of Environment, relied on the Advisory Committee for the Prevention of Disaster Natural Risk (COPRNM) through a dedicated Working Group.

This national Committee being the national platform for disaster risk reduction included parties interested in all natural hazards: flooding, earthquakes, landslides, etc.

\subsubsection{A flood governance at all levels}

For the implementation of the Floods Directive, the Ministry of Environment engages in a national structuring of parties around 3 levels of flood governance:

- nationally, a Joint Flood Commission (CMI) has been created based for all parties (State, elected representatives, trade unions, syndicate and NGOs) from the COPRNM but also the National Water Committee (CNE);

- at the river basin district level, a Flood District Commission (CIB);

- locally with the Local Public River Basin Establishment (EPTB) and Local Public Water Management Establishment (EPAGE).

Thus the CMI has taken over the writing of the national strategy with the DRR, urban planning stakeholders and water management stakeholders.

\subsection{Common objectives}

\subsubsection{Major objectives}

The French National Flood Risk Management Strategy [2] sets 3 major objectives:

- To improve the safety of exposed populations

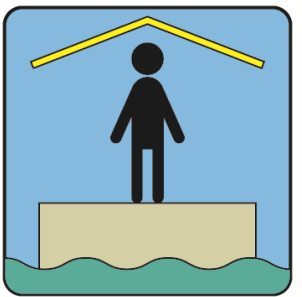

- To stabilise in the short term and reduce in the medium term the cost of flood damage

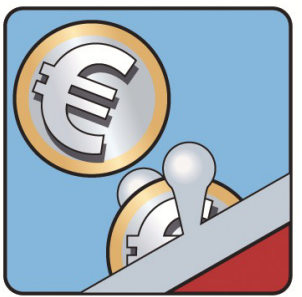

- To significantly shorten the time required by affected areas to return to normal

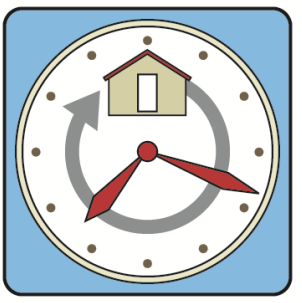

After years of trade off, all stakeholders agreed that floods may cause populations to face serious and even mortal risk. Therefore, the first national priority aims to reduce any loss of human life.

\subsubsection{Action framework}

The French National Flood Risk Management Strategy (SNGRI) also defines the guiding principles serving the three major objectives:

- Solidarity principle: Achieving these national objectives requires first and foremost, applying the solidarity principle when faced with risks. Governance applied to the management of flood risks, regardless of its geographical scale, reinforces this solidarity. Flood national policy is based on river basin level cooperation between stakeholders at the river basin level: upstream and downstream stakeholders, urban and rural areas, the living basin and the risk basin, the run-off basin, the hydrosedimentary cell along the coast. The insurance national solidarity principle is also the basis of French disaster risk reduction solidarity.

- Subsidiarity principle: The subsidiarity principle aims to ensure that decisions are taken as closely as possible to the citizen and that each action is implemented in light of the possibilities available at national, regional or local level: 
- Central government guarantees public safety alongside Mayors and conducts the flood risk prevention policy through state actions.

○ Municipalities or the public establishments for inter-city cooperation with their own taxation powers (EPCI) are a part of the stakeholders, with responsibility in terms of urban development and territorial development.

- Mayors are tasked with providing emergency services to the population. They develop municipal safeguard plans by informing and alerting community on on any risks

- $\quad$ Public policy synergy principle: Synergies between the various public policies relating to flood management lead to greater efficiency and cost rationalisation. It allows taking the impact of flooding into account in development projects or in the work done to preserve the natural habitat. Through this principle, the SNGRI established the flood risk management policy as an integrated policy addressing territorial policies (water, urban planning, infrastructure, etc.)

- Prioritisation and continuous improvement principle: To take into account the human, technical and financial resources that can be mobilised by each of the players involved, the national policy utilizes the prioritisation principle. The expected prioritisation-based scheduling is based on:

o selecting territories facing a severe risk, the areas of potential significant flood risks (APSFR), within each major basin,

- supporting relevant territorial projects addressing exposed territories with a cost-benefit and multiple criteria analyses to identify the measures that are economically sustainable.

\subsubsection{Strategic orientations: Four challenges to meet}

Stakeholders also identify four challenges for the implementation of the major objectives:

- Developing governance and project management: The sharing of roles and responsibilities in risk management is finalised in an organisational and financial framework. If the creation of the CMI, CIB, EPTB and EPAGE has enabled to frame flood governance, locally municipalities can mobilize and cooperate in stronger structure

- Sustainable territorial development: Taking into account the flood risk as part of a sustainable development approach for territories aiming to improve their competitiveness and getting more attractive.

- Increase knowledge to improve risk management: Looking beyond the expertise already gained, tools and methods have been developed to ensure an operational knowledge of territorial vulnerability when faced with flooding.

- Learning to live with floods: A mobilisation of all citizens, for which Mayors are the first representatives, requires being placed in a "crisis situation" illustrated by real life information and aimed at finding operational solutions.

\subsubsection{An interministerial strategy}

The French National Flood Risk Management Strategy has been adopted on October, the 7th 2014 by an interministerial decree from the Ministers of Environment, Interior, Agriculture and Housing. This adoption gives a strong strength to this framework in order to overtake barrier of policies, ministries and parties.

\section{An inclusive national outline}

\subsection{A tool for each scale}

The strength of the French transposition of the Flood Directive was to rebuild the entire flood management national policy. Thus from a national framework, the SNGRI, a chain of tools has been created to implement the SNGRI and the Flood Directive at each level according to the Subsidiarity principle:

- At River basin District level, the national strategy is implemented by a Flood Risk Management Plan (FRMP) that defines the objectives and measures in terms of flood risk management for the district [3].

- At River basin scale, for each APSFR, a local strategy clarifies the common objectives and measures of stakeholders for flood risk management.

- Theses local strategies will be implemented through flood prevention actions programs (PAPI) providing state financing through a national call for proposals.

- At a municipal level with the urban planning, Flood Risk Prevention Plan (PPRI), administrative decisions in the field of water policy have to be compatible with the FRMP assuring the implementation of national objectives 


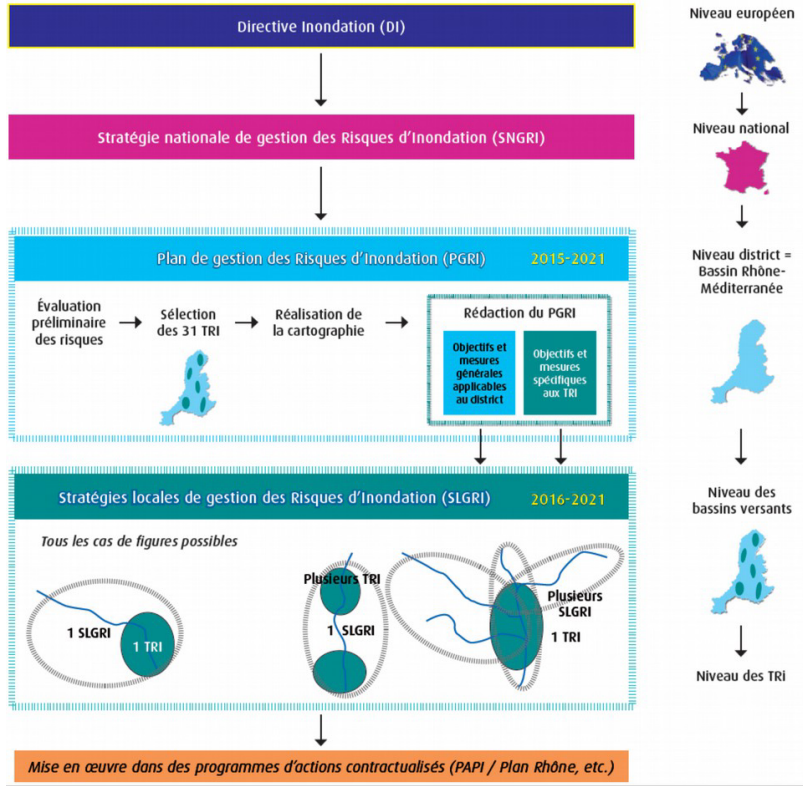

Figure 2. Illustration of flood management tools at all levels

\subsection{A balance between state control and local governance}

\subsubsection{The responsibility of local authorities}

For decades, local authorities had the responsibility for flood management like taking into account flood risk in their urban plans, preparing and managing crises in case of a flooding. But the new national flood risk management policy consecrates the role of local authorities in flood management at the same time as confirming the subsidiarity principle. The creation of new administrative structures like EPTB and EPAGE, as well as the creation of a Water Management and Flood Prevention competency for intercommunal structures (GEMAPI) is the result of a long evolution. The turning point of this movement could be situated in 2002 with the first flood prevention actions programs (PAPI) call for proposals addressed to local governance to promote innovation actions for flood risk management at a river basin scale. The GEMAPI competency and the management by local authorities of the local strategies for flood risk management is the completion of this revolution.

\subsubsection{State as public security guarantor}

But at the same time the State keeps the main responsibilities for flood risk management in association with stakeholders:

- FRMP is under the responsibility of the District Coordinator Prefect

- Flood and coastal risk prevention plans (PPRI\&PPRL), the strongest tool at municipal scale to manage flood risk are under the responsibility of the
Departmental Prefect, these tools can ban new constructions in floodplains but also control land use, activities, and order measures to reduce the vulnerability of existing assets (houses, building, factories...)

Thus the new French Flood Risk Management Policy succeeds in summarizing an integrated policy based on the subsidiarity principal with governance and tools at all levels by combating land pressure and encroachment of human activity (housing, production, services...) into floodplains.

\section{References}

1. Directive $2007 / 60 / \mathrm{CE}$ of the European Parliament and of the Council of October 23, 2007 related to the evaluation and management of flood risks

2. French national flood risk management strategy, 7th October 2014, adopted by the Ministers of Environment, Interior, Agriculture and Housing, www.developpementdurable.gouv.fr/document 152633

3. French national flood risk management policy www.developpement-durable.gouv.fr/Lastrategie-nationale-de-gestion, 40051.html 